\title{
Analysis of marathon performances of disabled athletes
}

\author{
Lepers, R ; Stapley, P J ; Knechtle, B
}

DOI: https://doi.org/10.1051/sm/2013078

Other titles: Analyse des performances sur marathon des athlètes handisports

Posted at the Zurich Open Repository and Archive, University of Zurich ZORA URL: https://doi.org/10.5167/uzh-106752

Journal Article

Accepted Version

Originally published at:

Lepers, R; Stapley, P J; Knechtle, B (2014). Analysis of marathon performances of disabled athletes. Movement Sport Sciences, (84):43-50.

DOI: https://doi.org/10.1051/sm/2013078 


\title{
Analysis of marathon performances of disabled athletes
}

\section{Analyse des performances sur marathon des athlètes handisports}

\author{
Romuald Lepers ${ }^{1}$, Paul J. Stapley ${ }^{2}$, Beat Knechtle ${ }^{3}$ \\ ${ }^{1}$ INSERM U1093, Faculty of Sport Sciences, University of Burgundy, \\ Dijon, France \\ ${ }^{2}$ School of Health Sciences, Faculty of Health and Behavioural Sciences, University of \\ Wollongong, Australia \\ ${ }^{3}$ Institute of General Practice and for Health Services Research, University of Zurich, \\ Zurich, Switzerland
}

Running title: marathon performances of disables athletes

\section{Corresponding author}

Romuald Lepers

INSERM U1093

UFR STAPS

BP 27877

21078 Dijon Cedex

France

Tel : +33.3 .80 .39 .67 .60$

Fax : +33.3.8.39.67.02

e-mail: romuald.lepers@u-bourgogne.fr 
Analysis of marathon performances of disabled athletes

Analyse des performances sur marathon des athlètes handisports

Running title: marathon performances of disables athletes 


\section{Résumé}

Le but de cette étude était d'analyser la participation et les performances sur marathon des athlètes handisports en fauteuils roulants classiques (WC) et en fauteuils avec pédalage des bras ou Handbike (HC). L'âge et les performances chronométriques de tous les athlètes ayant participé au marathon de New-York, dans les catégories WC et HC, ont été analysés entre 1999 et 2010. Durant cette période, un total de 698 athlètes WC (132 femmes et 566 hommes) et 776 athlètes HC (141 femmes et 635 hommes) ont terminé la course. Les femmes représentaient $\sim 20 \%$ du total des arrivants dans les deux catégories. Les athlètes en catégorie WC était significativement $(P<0.01)$ plus jeunes en comparaison des athlètes $\mathrm{HC}$, aussi bien chez les femmes que chez les hommes. Chez les hommes, les performances chronométriques étaient meilleures $(P<0.01)$ pour les athlètes HC que pour les athlètes WC. Depuis 2003, la différence de performance entre les hommes et les femmes s'est stabilisée aux alentours de $25 \%$ pour les athlètes WC, alors qu'elle était plus variables (15-45\%) pour les athlètes HC.

Des études ultérieures devront expliquer pourquoi sur marathon les athlètes HC sont plus âgés que les athlètes WC, et pourquoi la différence de performance au marathon entre les hommes et les femmes est plus grande dans les catégories handisports que pour les athlètes valides.

Mots clés: endurance; différence des genres; athlète handisport, fauteuils roulants sportifs 


\begin{abstract}
The aim of this study was to examine the participation and performance trends in wheelchair marathon for wheelchair (WC) and hand cycle (HC) athletes. Age and time performance data for all athletes in the WC and HC categories who completed the 'New York City Marathon' from 1999 to 2010 were analyzed. During this period, there were 698 total finishers (132 women and 566 men) for WC athletes and 776 total finishers (141 women and 635 men) for $\mathrm{HC}$ athletes. Women accounted for $\sim 20 \%$ of the total field for both categories. For both men and women, the age of the winner and the mean age of all finishers were significantly $(P<$ 0.01) younger for WC compared with $\mathrm{HC}$ athletes. For men, the race times were significantly $(P<0.01)$ shorter for the HC winner and overall finishers compared with WC counterpart. Since 2003, the sex difference in time performances for WC athletes stabilized at $~ 25 \%$, while the sex difference for $\mathrm{HC}$ athletes was more variable (15-45\%). Future studies need to investigate the reasons why HC marathoners are older than WC marathoners and why the sex differences in marathon performance are much greater for disabled athletes than for ablebodied athletes.
\end{abstract}

Key words: endurance; sex difference; disabled athlete; spinal cord injury 


\section{Introduction}

When wheelchair (WC) sports first gained in popularity, they were seen as a method of rehabilitation to increase the physical activity of wheelchair-bound persons. Since then, however, wheelchair sports have expanded to become competitions for WC athletes (Bhambhani et al., 2010; Cooper, 1990). They have now developed predominantly for people with spinal cord injuries, and have contributed greatly to the improvement of physical fitness and the social interaction of handicapped people (Ogata, 1994).

Wheelchair racing is competitive racing of WC athletes and can be performed on the track or on the road. Wheelchair races are open to athletes with different types of disability, such as amputees, spinal cord injuries, or athletes with cerebral palsy. Disabled athletes can compete at different distances up to the marathon distance (Corcoran et al., 1980; Ogata, 1994). At the present time, there are numerous international WC road races around the world, such as specific WC marathons in which only WC athletes can participate (e.g. Oita in Japan, Lepers et al. 2012) or international marathons in which both WC and hand cycle athletes perform on the same course as able-bodied athletes (e.g. New York City Marathon, Boston Marathon).

Traditionally, WC athletes compete in specific race wheelchairs. More recently, however, a new category of hand cycling (HC) was introduced into WC races. Hand cycling began in the 1980 's as a recreational sport. Initially, competitive WC equipment was hard to find, and the equipment that did exist was clunky and expensive (www.handcycling.sg/Handcycling). Hand cycling was approved as part of the International Paralympic Committee (IPC) cycling program in 1988 and was included at the World Cycling Championships for disabled athletes that same year (www.cyclesport.com). Later in 1996, track HC was included in the Atlanta Paralympic 
Games. The IPC included a road race for HC (men only) at the Paralympic Games in 2004 at Athens (Greece) and later in 2008 some track and road events (i.e. men and women) in the Beijing 2008 Paralympic Games (www.handcycling.sg/Handcycling).

The main differences between $\mathrm{WC}$ and $\mathrm{HC}$ are the sitting positions assumed and the arm movements needed to propel the chair. In a classical race WC, the athletes are sitting with their legs bent and they have to bend their lumbar spine forwards and backwards to push the wheel of the WC with their hands. In the HC, the athletes sit on a chair in a supine position with their legs straight. They rotate the wheels using parallel, out-of-phase movements of the arms on a crankset to transmit the power to the wheels via a chain (Marshall, 1984; Van der Woude, Bosmans, Bervoets \& Veeger, 2000). In addition, hand cyclists can change gears to adapt to the elevation of the road and it gives them some advantage compared with classical race $\mathrm{WC}$ on level terrain. In terms of the physiological differences between $\mathrm{WC}$ cycling and HC cycling, it has been shown that although athletes have different sitting postures, road race WC athletes seem to reach a higher maximum oxygen uptake $\left(\mathrm{VO}_{2} \mathrm{max}\right)$. For example, Knechtle, Müller, Willmann, Eser and Knecht (2004) and Knechtle, Müller, and Knecht (2004) found that road race WC athletes could reach a maximal oxygen uptake $\left(\mathrm{VO}_{2}\right.$ peak) of $40.2 \pm 6.7 \mathrm{ml} \cdot \mathrm{kg}^{-1} \cdot \mathrm{min}^{-1}$ whereas hand cyclists only reached a $\mathrm{VO}_{2}$ peak of $37.5 \pm 7.8 \mathrm{ml} \cdot \mathrm{kg}^{-}$ ${ }^{1} \cdot \min ^{-1}$.

Participation and performances trends in marathon running performance have been previously investigated for able-bodied athletes (Lepers \& Cattagni, 2012; Leyk et al., 2009). Since the early 1980's, participation in marathon running has skyrocketed with hundreds of marathons worldwide and several events having more than 40,000 participants (Lepers \& Cattagni, 2012). In terms of performance, elite athletes have slightly improved their marathon 
performances over the past three decades (La Torre, Vernillo, Agnello, Berardelli \& Rampinin, 2011), but older athletes - master athletes older than 50 years of age - improved at a greater rate than younger athletes (Lepers \& Cattagni, 2012; Leyk et al., 2009). To date however, no documented data exists regarding the participation and performance trends in $\mathrm{WC}$ and $\mathrm{HC}$ athletes at the marathon distance.

Previous studies have shown that the sex difference in marathon running performance for elite able-bodied athletes corresponded to $\sim 10-12 \%$ of overall finish time (Hunter, Stevens, Magennis, Skelton \& Fauth, 2011; Lepers \& Cattagni, 2012; Sparkling, O’Donnell \& Snow, 1998). Physiological and morphological differences between men and women, such as percentage body fat, oxygen carrying capacity and running economy may be responsible for the sex differences recorded in running performance (Levis, Kamon \& Hodgson, 1986). Compared with women, male runners are stronger and have a greater aerobic capacity. Even when $\mathrm{VO}_{2}$ max is expressed relative to lean body mass, men still retain an aerobic performance advantage (Drinkwater, 1984). In contrast to running that involves primarily leg muscles, WC and HC involves primarily the muscles of the upper body. However, gender difference is greater in upper body strength than in lower body strength probably because women tend to have a lower proportion of their lean tissue distributed in the upper body (Miller, MacDougall, Tarnopolsky \& Sale, 1993). With these differences of the primary muscles groups involved in mind, it is therefore interesting to analyze the sex difference in $\mathrm{WC}$ and $\mathrm{HC}$ performances to investigate if the gap between men and women is greater to that observed for able-bodied runners, recruiting primarily the leg muscles.

Therefore, a first purpose of this study was to examine the changes in participation and performance of WC and HC athletes at the 'New York City Marathon' from 1999 to 2010. A 
secondary purpose was to analyze the sex differences in performance for both WC and HC athletes. 


\section{Materials and methods}

Approval for this study was obtained from the Burgundy University Committee on Human Research. It involved the analysis of publicly available data so consent was waived. Age and time performance data for all athletes in the WC and $\mathrm{HC}$ categories who completed the 'New York City Marathon' from 1999 to 2010 were obtained through the web site (www.ingnycmarathon.org). We did not consider the results prior 1999 because WC and HC athletes were pooled into the same division. In the present paper, we focused our attention on the 'New York City Marathon' because it is one of the largest marathons in the world, with more than 45,000 finishers in 2010 (Lepers \& Cattagni, 2012; Leyk et al., 2009) and it is among the pre-eminent long-distance annual running events in the United States.

Data (i.e. age and time performance) were analyzed for the winners (first place) and were also averaged across the first three overall men and women for both WC and $\mathrm{HC}$ athletes from 1999 to 2010 . The magnitude of sex differences was examined by calculating the percent difference for times between both the winners and the top three men and women.

\section{Statistical analysis}

Values are reported as means \pm 1 SD within the text and displayed as means \pm 1 SE in the figures. Statistical analysis was performed using the STATISTICA Software for Windows (Version 6.0). Size effect was calculated by the Cohen's $d$ and was defined as small for $d=$ 0.2 , medium for $d=0.5$ and large for $d=0.8$. Two-way ANOVAs [(category (WC, HC) $\mathrm{x}$ year)] with repeated measures on year, were used to compare age and time performances of the athletes between the categories, for both men and women. Post hoc analyses (Tukey) were 
used to test main effect differences within the ANOVAs when appropriate. A significance level of $P<0.05$ was used to identify statistical significance. 


\section{Results}

\section{Participation trends}

From 1999 to 2010, there were 698 total finishers (132 women and 566 men) for WC athletes and 776 total finishers (141 women and 635 men) for HC athletes at the 'New York City Marathon'. The number of finishers each year over the history of the event is shown in Figure 1. During the 1999-2010 period, the average total number of WC and HC finishers per year was $123 \pm 22$ (range, $89-159$ ). The average number of finishers per year was $47 \pm 16$ (range, 30 -


8-81) for men $\mathrm{HC}$ athletes and $12 \pm 5$ (range, 5-20) for women $\mathrm{HC}$ athletes, respectively. Over the same 12-year period, women accounted on average for $19.6 \pm 5.2 \%$ of the field for the WC category and for $19.5 \pm 7.2 \%$ of the field for HC category, respectively.

\section{Age of the WC and HC athletes}

Figure 2 shows the historical age trends of the male and female winners, the top three men and women finishers and overall finishers between 1999 and 2010, for both WC and HC athletes. There was no significant category $\mathrm{x}$ year interaction for age of the winner, top three finishers and overall finishers. Independently of year, the age of the athletes differed between WC and HC categories $(P<0.001)$. The winners were significantly $(P<0.01)$ younger for WC than for HC category for both men (31 \pm 5 versus $46 \pm 7$ years, Cohen's $d=2.4$ ) and women (33 \pm 8 versus $48 \pm 13$ years, Cohen's $d=1.4$ ), respectively (Figure 2, Panels A and B). Similarly, the top three WC finishers were significantly $(P<0.01)$ younger than the top three HC finishers for both men (35 \pm 3 versus $42 \pm 7$ years, Cohen's $d=1.3)$ and women $(28 \pm 4$ versus $43 \pm 7$ years, Cohen's $d=2.6$ ), respectively (Figure 2, Panels C and D). During the studied period, the mean age of the finishers was significantly $(P<0.01)$ younger for WC 
than for HC athletes for both men (men WC: $36 \pm 2$ years old; men HC: $43 \pm 3$ years old, Cohen's $d=2.7$ ) and women (women WC: $33 \pm 3$ years old; women HC: $46 \pm 4$ years old, Cohen's $d=3.7$ ) athletes, respectively (Figure 2, Panels E and F).

\section{Time performances of the WC and HC athletes}

Figure 3 shows the historical performance trends of the male and female winners (Panel A and B), top three men and women finishers (Panel C and D) and overall finishers (Panel E and F) between 1999 and 2010, for both WC and HC athletes. For men, there was no significant category $\mathrm{x}$ year interaction for performance time of the winner, top three and overall finishers. Independently of years, the performance times differed between WC and HC categories $(P<$ 0.001). The men winner times were significantly $(P<0.01)$ shorter for HC compared with WC athletes $(1: 31 \pm 0: 15$ versus 1:39 $\pm 0: 10$ h:min, Cohen's $d=0.62)$. The top three male finishing times were significantly $(P<0.01)$ shorter for $\mathrm{HC}$ compared with WC athletes (1:36 $\pm 0: 17$ versus 1:41 $\pm 0: 10$ h:min, Cohen's $d=0.35)$. Similarly, the mean times of all men finishers were significantly $(P<0.01)$ shorter for HC compared with WC finishers $(2: 42 \pm 0: 12$ versus 3:50 $\pm 0: 29$ h:min h:min, Cohen's $d=3.06$ ).

For women, there was no significant category $\mathrm{x}$ year interaction for performance time of the winner, top three finishers and overall finishers. The female winning times were significantly $(P<0.01)$ shorter for HC compared with WC athletes (1:53 $\pm 0: 11$ versus 2:12 $\pm 0: 29$ h:min, Cohen's $d=0.86$ ). In contrast, the top three women finishing times were not significantly different between HC and WC athletes $(2: 10 \pm 0: 14$ h:min for HC; $2: 25 \pm 0: 41 \mathrm{~h}: \min$ for WC, Cohen's $d=0.48$ ). Similarly, the mean times of all women finishers did not differ between HC and WC finishers (3:49 $\pm 0: 22$ h:min for WC and 3:44 $\pm 0: 18$ h:min for HC, Cohen's $d=$ $0.24)$. 
Sex differences in time

The sex differences in time for the winners and for the top three finishers are presented in Figure 4 for both HC and WC athletes. The average time difference between the men and women winners corresponded to $25 \pm 17 \%$ for $\mathrm{WC}$ athletes and $32 \pm 16 \%$ for $\mathrm{HC}$ athletes, respectively (Figure 4A). The average time difference between the top three male and female athletes was equal to $40 \pm 25 \%$ for WC athletes and $38 \pm 18 \%$ for $\mathrm{HC}$ athletes, respectively (Figure 4B). Since 2003, the sex difference in time for the winner and top three WC athletes stabilized to around $25 \%$ while the sex differences for $\mathrm{HC}$ athletes were more stochastic (15$45 \%)$. 


\section{Discussion}

The main findings of the present study were first that WC athletes were significantly younger than $\mathrm{HC}$ athletes for both women and men at the 'New York City Marathon' (women representing $20 \%$ of the total field). Second, the best male HC athletes are nowadays $~ 20 \%$ faster than the male WC ones, but in contrast the best female $\mathrm{HC}$ and $\mathrm{WC}$ athletes achieved similar levels of performance. Third, the sex difference in marathon performances for WC athletes stabilized at $25 \%$ since 2003 while the sex difference for $\mathrm{HC}$ athletes was more variable $(15-45 \%)$.

\section{Participation trends}

During the 1999-2010 period, among the $~ 35,000$ annual finishers of the 'New York City Marathon' (Lepers \& Cattagni, 2012; Leyk et al., 2009), 130 finishers belonged to WC or $\mathrm{HC}$ categories. Even if the rate of participation of WC and $\mathrm{HC}$ athletes at the 'New York City Marathon' seems low at less than $0.4 \%$ of all competitors, it corresponds to the rate of wheelchair users of 18-64 years old in the general population in the United States (http://dsc.ucsf.edu/publication.php). This suggests that the desire to complete a marathon is similar between able-bodied and handicapped people. Women WC and $\mathrm{HC}$ athletes represented $\sim 20 \%$ of the field while it has been shown that able-bodied women athletes represented $\sim 33 \%$ of the total finishers at the 'New York City Marathon' (Lepers \& Cattagni, 2012; Leyk et al., 2009). The reasons for a lower relative participation of women in the handicapped field compared with able-bodied field remains to be elucidated. Potential factors might be motivational (Krouse, Ransdell, Lucas \& Pritchard, 2011; Wu \& Williams, 2001) or orthopaedic (Curtis \& Black, 1999; Curtis et al., 1999) reasons. Wu and Williams (2001) 
reported that the main reasons for athletes with spinal cord injury to participate in sports after injury were fitness, fun, health, and competition; although many athletes noted that social aspects and rehabilitation also influenced their participation. An important factor that cannot be ignored is that women have a lower muscle mass and are thus more prone to developing orthopedic disorders associated with moving the $\mathrm{WC}$ or $\mathrm{HC}$ forwards. In this regard, Curtis \& Black (1999) reported that over 90\% of women wheelchair basketball players complained about shoulder pain while in general, shoulder pain is present in $\sim 59 \%$ of the subjects with tetraplegia and $\sim 42 \%$ of the subjects with paraplegia (Curtis et al., 1999).

When we examined the different rates of participation of $\mathrm{HC}$ and $\mathrm{WC}$ men athletes during the 1999-2010 period, it appeared that since 2004, the number of HC finishers has grown compared with WC finishers. Historically, $\mathrm{HC}$ developed later than $\mathrm{WC}$ and it seems that the expansion of $\mathrm{HC}$ is now greater than $\mathrm{WC}$ at least in the sport community. Potential reasons for this increase might be related to technical aspects. Since athletes move forwards differently on a hand cycle compared with a classical race wheelchair, shoulder pain might be less prevalent. Arnet, van Drongelen, van der Woude and Veeger (2012) showed that due to the circular movement and the continuous force application during hand cycling, the glenohumeral contact forces, as well as the muscle forces were clearly lower compared with the results in the existing literature on wheelchair propulsion. They assumed that hand cycling is mechanically less stressful on the joints than handrim wheelchair propulsion, which may help preventing overuse to the shoulder complex. Regular hand cycle training leads to less shoulder pain. It has been shown that patients with tetraplegia that were allowed to perform physical activities could improve their physical capacity through regular hand cycle interval training, without participant-reported shoulder-arm pain or discomfort (Valent et al., 2009). Due to the comfortable sitting position, hand cyclists have even been able to finish a 540-km 
race with an average speed of $21.6 \mathrm{~km} \cdot \mathrm{h}^{-1}$ and within a total race time of $38 \mathrm{~h} 52 \mathrm{~min}$ (Abel, Burkett, Schneider, Lindschulten \& Strüder, 2010).

Interestingly, WC athletes were significantly younger than $\mathrm{HC}$ athletes for both women and men. Potential explanations could be that athletes started with WC cycling and changed later in life to HC cycling when they become older. It is also possible that older individuals would not expose their shoulders to more stress and decided to go for HC over WC. Also, the more supine position in the hand cycle is probably more comfortable for older athletes than in the race wheelchair. Motivation might also play a role (Kosel, 1993). Wheelchair athletes in track races compete at a very high level. While older athletes focus more on the psychosocial benefits of sport (Sporner et al., 2009), younger athletes may be rather more motivated to win (Skordilis, Gavriilidis, Charitou \& Asonitou, 2003).

\section{Performances trends}

In 1999, the best WC and HC men athletes had similar levels of performance than best ablebodied runners in the marathon, with race times close to $2 \mathrm{~h} 10 \mathrm{~min}$. However, performances of WC and HC athletes have improved from 1999 to 2003 and tend to stabilize nowadays. For example, in 2010 , top three WC male athletes were $\sim 24 \%$ faster $(\sim 1 \mathrm{~h} 38 \mathrm{~min})$ and HC male athletes $\sim 42 \%$ faster ( $\sim \mathrm{h} 21 \mathrm{~min})$ compared with the top three male able-bodied athletes that ran in $\sim 2 \mathrm{~h} 09 \mathrm{~min}$. The difference in performance between handicapped and able-bodied athletes is less pronounced for women. Indeed, the top three WC and $\mathrm{HC}$ female athletes were $\sim 14 \%$ faster ( 2h07min) than their able-bodied counterparts in 2010. Substantial improvements in training, materials and technique could explain the largest progresses until 2003, while nowadays such improvements are more limited. Training in WC athletes has made progress and improved since intense physical training via wheelchair propulsion can 
markedly enhance upper body cardiovascular fitness in spinal cord injured paraplegics (Hooker \& Wells, 1992).

Over the past decade, $\mathrm{HC}$ male athletes have been faster than their WC counterparts. The best male $\mathrm{HC}$ athletes are nowadays $\sim 20 \%$ faster than male WC ones, but in contrast, the best female $\mathrm{HC}$ and WC athletes achieved similar levels of performance. A possible explanation for faster times in men $\mathrm{HC}$ compared with men WC athletes could be that in $\mathrm{HC}$ more muscle mass of the upper body could be involved and therefore the propulsion of the $\mathrm{HC}$ could be enhanced. Female $\mathrm{HC}$ athletes seem to not have the same benefices as men compared to WC athletes, possibly due to their lower muscle strength in upper body compared to their male counterpart. Otherwise, technical aspects such as aerodynamics and the possibility of changing gears with $\mathrm{HC}$ may also give an advantage to $\mathrm{HC}$ athletes in term of overall mobility speed.

\section{Sex difference in performance}

Since 2003, when time performances have plateaued, the sex difference in WC marathon performance stabilized at $\sim 25 \%$. In accordance with this finding, Lepers et al (2012) found that the mean gender difference in time at the Oita international wheelchair marathon was around $26 \%$. For HC, the sex difference showed rather large fluctuations across the years but remained greater than $25 \%$ for the top three athletes. These values are much greater compared with traditional values around $10-12 \%$ reported in the literature for able-bodied runners (Hunter, Stevens, Magennis, Skelton, \& Fauth, 2011; Lepers \& Cattagni, 2012; Sparkling, O’Donnell \& Snow, 1998). Coutts and Schutz (1988) have reported that sex differences in performance were $15 \%$ for $200 \mathrm{~m}$ and $23 \%$ for the $5,000 \mathrm{~m}$ track, respectively. These data suggest that with increasing length of a wheelchair race, the sex differences increase. Several 
factors could explain the greater sex difference in marathon performance between handicapped and able-bodied athletes. Firstly, marathon WC racing attracted less female than male handicapped athletes. Indeed, the rate of participation is lower for female WC athletes ( $20 \%)$ compared with female able-bodied runners ( $\sim 33 \%)$. Secondly, sex differences in anthropometry such as lower skeletal muscle mass of the upper limbs of women compared to men may limit the power production during a 2-h effort such marathon. To date, comparison of physiological factors related to endurance performance (e.g. maximal aerobic capacity, lactate threshold and efficiency) between men and women WC athletes are still be studied.

\section{Limitations and implications for future research}

In this data analysis, the level of the lesion of the spinal cord following American Spinal Injury Association (ASIA) Impairment Scale (AIS) was not considered. Due to the small number of disabled marathoners, we focused on the results from the overall ranking without respect to the classification of the International Stoke Mandeville Wheelchair Sports Federation (ISMWSF). In addition, boosting using autonomic dysreflexia (Bhambhani et al., 2010), which can enhance endurance performance in spinal cord injured athletes, was not controlled for in this study. A framework for pre-participation evaluation, training program and injury prevention is required to help disabled endurance athletes reach their participation and performance goals injury free i.e. to maximise the benefits and minimize the risks.

\section{Conclusion}

Hand cycle and wheelchair marathon performances have not attracted a great deal of interest from sport scientists. This paper is the first to describe the specific aspects of the HC and WC marathon with regard to participation, performance and sex. It appears that $\mathrm{HC}$ athletes are on average older than WC ones. Men HC athletes achieve now better marathon performance than 
WC counterparts while performances are similar between $\mathrm{HC}$ and $\mathrm{WC}$ women athletes. The specific aspects of locomotion with WC and HC may explain why sex differences in marathon performance are greater for WC and $\mathrm{HC}$ compared with able-bodied runners. Future studies will need to focus on the physiological basis of WC and $\mathrm{HC}$ athletes and how they differ each other. During the 1999-2010 period, 6 men athletes (4 WC and $2 \mathrm{HC}$ ) and 8 women athletes (4 WC and $4 \mathrm{HC}$ ) finished several times in the top three overall. This redundancy was not taken into account in the present study and could maybe influence slightly some results. Future investigations using for example mixed modeling are required for analyzing the changes in performances across the years. Studies should also investigate the motivation of $\mathrm{WC}$ and $\mathrm{HC}$ to compete in these different races. It is hoped that the data will stimulate further research on physiological profile of endurance disabled athletes. 


\section{References}

Abel T, Burkett B, Schneider S, Lindschulten R, Strüder HK. The exercise profile of an ultralong handcycling race: the Styrkeprøven experience. Spinal Cord. 2010;48:894-898.

Arnet U, van Drongelen S, van der Woude LH, Veeger DH. Shoulder load during handcycling at different incline and speed conditions. Clinical Biomechanics (Bristol, Avon). 2012; 27:1-6.

Bhambhani Y, Mactavish J, Warren S, Thompson WR, Webborn A, Bressan E, De Mello MT, Tweedy S, Malone L, Frojd K, Van De Vliet P, Vanlandewijck Y. Boosting in athletes with high-level spinal cord injury: knowledge, incidence and attitudes of athletes in paralympic sport. Disability and Rehabilitation. 2010;32: 2172-2190.

Cooper RA. Wheelchair racing sports science: a review. Journal of Rehabilitation Research and Development. 1990; 27:295-312.

Corcoran PJ, Goldman RF, Hoerner E, Kling C, Knuttgen HG, Marquis B, McCann BC, Rossier AB. Sports medicine and the physiology of wheelchair marathon racing. Orthopedic Clinics of North America. 1980;11:697-716.

Coutts KD, Schutz RW. Analysis of wheelchair track performances. Medicine and Science in Sports and Exercise. 1998;20:188-194.

Curtis KA, Black K. Shoulder pain in female wheelchair basketball players. Journal of Orthopaedic and Sports Physical Therapy. 1999;29:225-231.

Curtis KA, Drysdale GA, Lanza RD, Kolber M, Vitolo RS, West R. Shoulder pain in wheelchair users with tetraplegia and paraplegia. Archives of Physical Medicine and Rehabilitation. 1999; 80:453-457.

Drinkwater BL. Women and exercise: physiological aspects. Exercise and Sport Sciences Reviews. 1984;12,:21-51.

Hunter SK., Stevens AA, Magennis K, Skelton KW, Fauth M. Is there a sex difference in the age of elite marathon runners? Medicine and Science in Sports and Exercise. 2001;43:656-664.

Hooker SP, Wells CL. Aerobic power of competitive paraplegic road racers. Paraplegia. 1992;30:428-436.

Knechtle B, Müller G, Willmann F, Eser P, Knecht H. Fat oxidation at different intensities in wheelchair racing. Spinal Cord;2004a;42:24-28.

Knechtle B, Müller G, Knecht H. Optimal exercise intensities for fat metabolism in handbike cycling and cycling. Spinal Cord. 2004b;42:564-572.

Kosel H. Competitive sports for handicapped patients. Motivation-attitude-facts. Rehabilitation (Stuttg). 1993;32:241-249. 
Krouse R. Ransdell LB, Lucas SM, Pritchard ME. Motivation, goal orientation, coaching, and training habits of women ultrarunners. Journal of Strength and Conditioning Research. 2011;25:2835-2842.

La Torre A, Vernillo G, Agnello L, Berardelli C, Rampinini E. Is it time to consider a new performance classification for high-level male marathon runners? Journal of Strength and Conditioning Research. 2011;25:3242-3247.

Lepers R, Cattagni T. Do older athletes reach limits in their performance during marathon running? Age (Dordr). 2012;34:773-781.

Lepers R, Stapley PJ, Knechtle B. Gender differences in wheelchair marathon performance Oita International Wheelchair Marathon from 1983 to 2011. Open Access Journal of Sports Medicine. 2012;3:169-174.

Levis DA, Kamon E, Hodgson JL. Physiological differences between genders. Implications for sports conditioning. Sports Medicine. 1986;3:357-369.

Leyk D, Erley O, Gorges W, Ridder D, Rüther T, Wunderlich M, Sievert A, Essfeld D, Piekarski C, Erren T. Performance, training and lifestyle parameters of marathon runners aged 20-80 years: results of the PACE-study. International Journal of Sports Medicine. 2009;30:360-365.

Marshall T. Wheelchairs and marathon road racing. British Journal of Sports Medicine. 1984;18:301-304.

Miller AE, MacDougall JD, Tarnopolsky MA, Sale DG. Gender differences in strength and muscle fiber characteristics. Eur J Appl Physiol Occup Physiol. 1993;66:254-262.

Ogata $\mathrm{H}$. A review of wheelchair marathon and tennis. Journal of University of Occupational and Environmental Health. 1994;16:201-217.

Skordilis EK, Gavriilidis A, Charitou S, Asonitou K. Comparison of sport achievement orientation of male professional, amateur, and wheelchair basketball athletes. Perceptual and Motor Skills. 2003;97:483-490.

Sparkling PB, O'Donnell EM, Snow TK. The gender difference in distance running performance has plateaued: an analysis of world rankings from 1980 to 1996. Medicine and Science in Sports and Exercise. 1998;30:1725-1729.

Sporner ML, Fitzgerald SG, Dicianno BE, Collins D, Teodorski E, Pasquina PF, Cooper RA. Psychosocial impact of participation in the National Veterans Wheelchair Games and Winter Sports Clinic. Disability and Rehabilitation. 2009;31:410-418.

Valent LJ, Dallmeijer AJ, Houdijk H, Slootman HJ, Janssen TW, Post MW, van der Woude LH. Effects of hand cycle training on physical capacity in individuals with tetraplegia: a clinical trial. Physical Therapy. 2009;89:1051-1060.

Van der Woude LH, Bosmans I, Bervoets B, Veeger HE. Handcycling: different modes and gear ratios. Journal of Medical Engineering and Technology. 200;24:242-249. 
Verellen J, Meyer C, Janssens L, Vanlandewijck Y. Peak and submaximal steady-state metabolic and cardiorespiratory responses during arm-powered and arm-trunkpowered handbike ergometry in able-bodied participants. European Journal of Applied Physiology. 2012;112:983-989.

Wu SK, Williams T. Factors influencing sport participation among athletes with spinal cord injury. Medicine and Science in Sports and Exercise. 2001;33:177-182. 


\section{Figure legends}

\section{Figure 1}

Number of finishers at the 'New York City Marathon' for wheelchair cycling (WC) and handbike cycling (HC) category from 1999 to 2010.

\section{Figure 2}

Changes in age of wheelchair cycling (WC) and handbike cycling (HC) athletes from 1999 to 2010 at the 'New York City Marathon'. Age of the overall male (Panel A) and female (Panel B) winners. Mean ( \pm SE) age of the overall top three male (Panel C) and female (Panel D) finishers. Mean $( \pm$ SE) age of the overall male (Panel E) and female (Panel F) finishers.

\section{Figure 3}

Changes in performance times of wheelchair cycling (WC) and handbike cycling (HC) athletes from 1999 to 2010 at the 'New York City Marathon'. Performance times of the overall male (Panel A) and female (Panel B) winners. Mean ( \pm SE) performance times of the overall top three male (Panel C) and female (Panel D) finishers. Mean $( \pm$ SE) performance times of the overall male (Panel E) and female (Panel F) finishers.

\section{Figure 4}

Changes in time sex difference of wheelchair cycling (WC) and handbike cycling (HC) athletes from 1999 to 2010 at the 'New York City Marathon'. Time sex differences of the overall winners (Panel A). Mean $( \pm$ SE) time sex difference of the overall top three finishers (Panel B). 
Figure 1

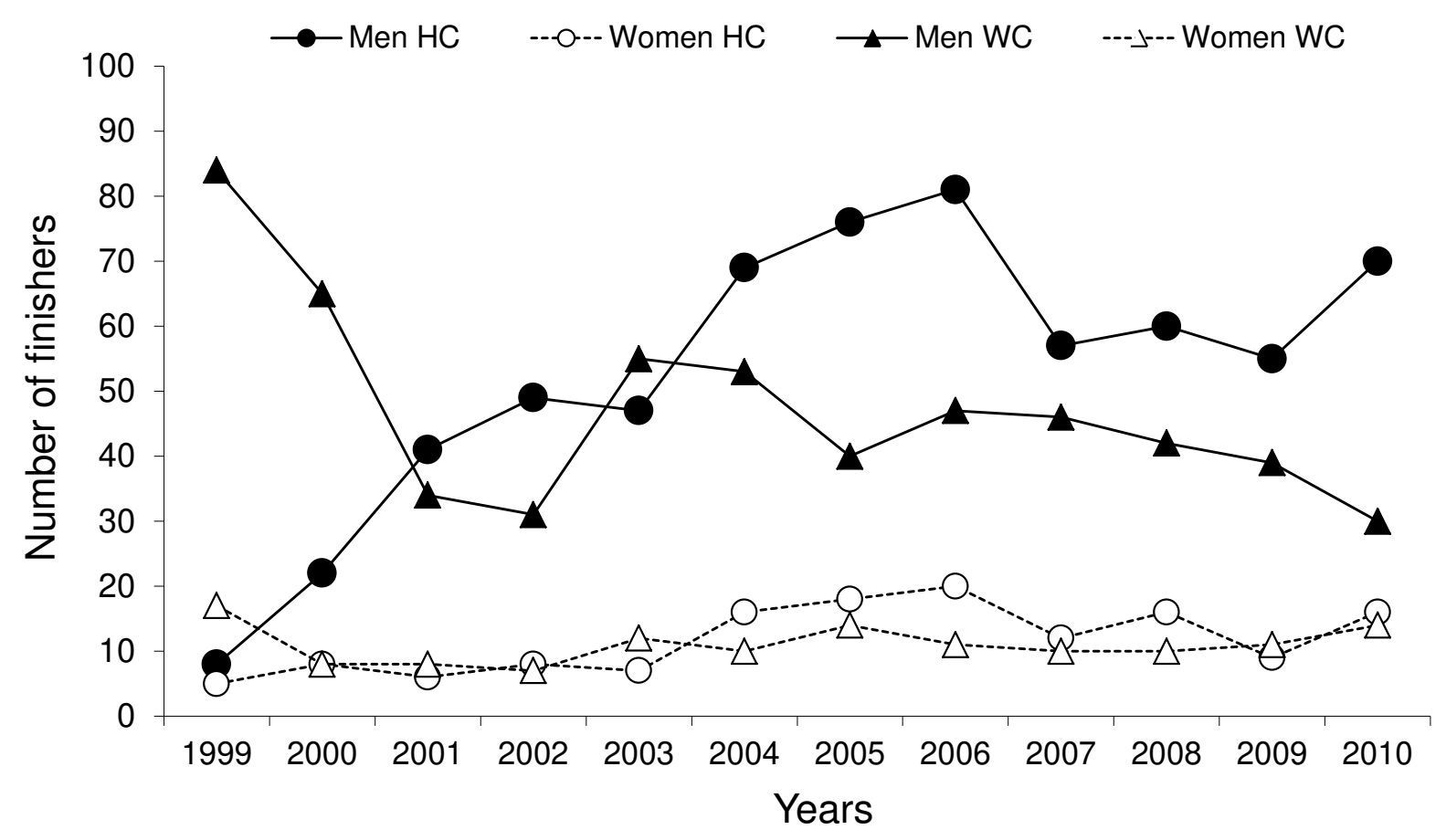


Figure 2
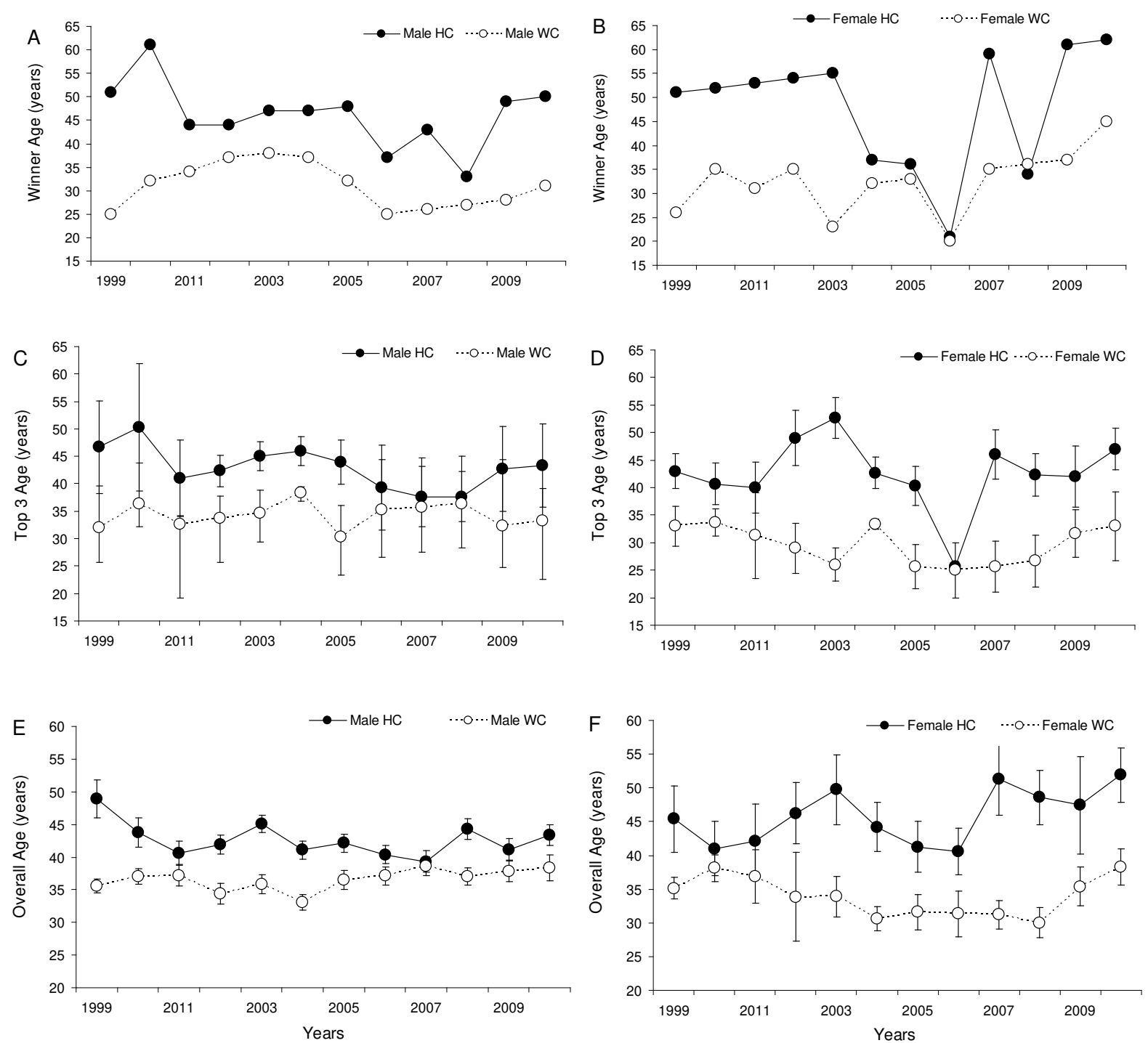
Figure 3
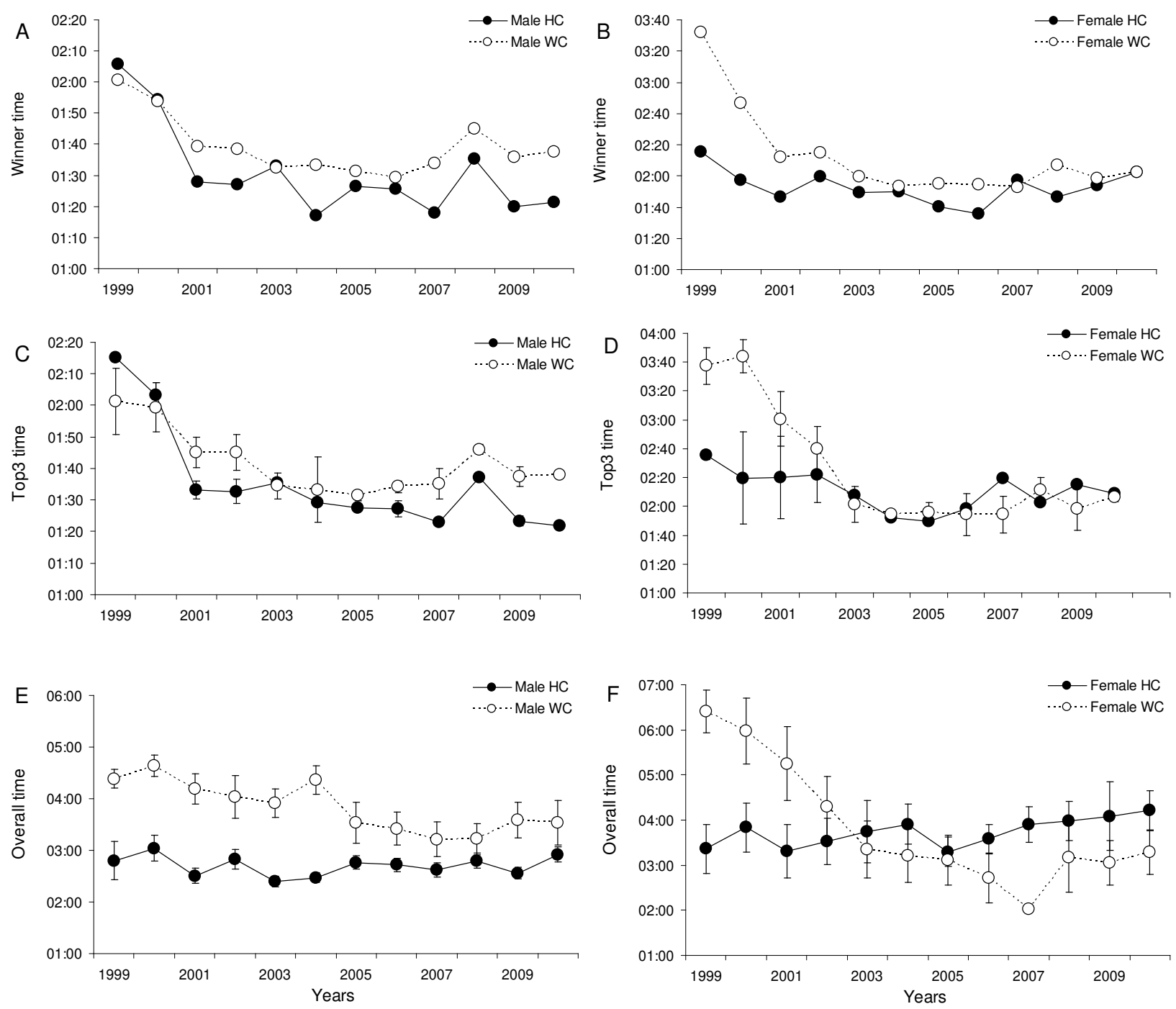
Figure 4
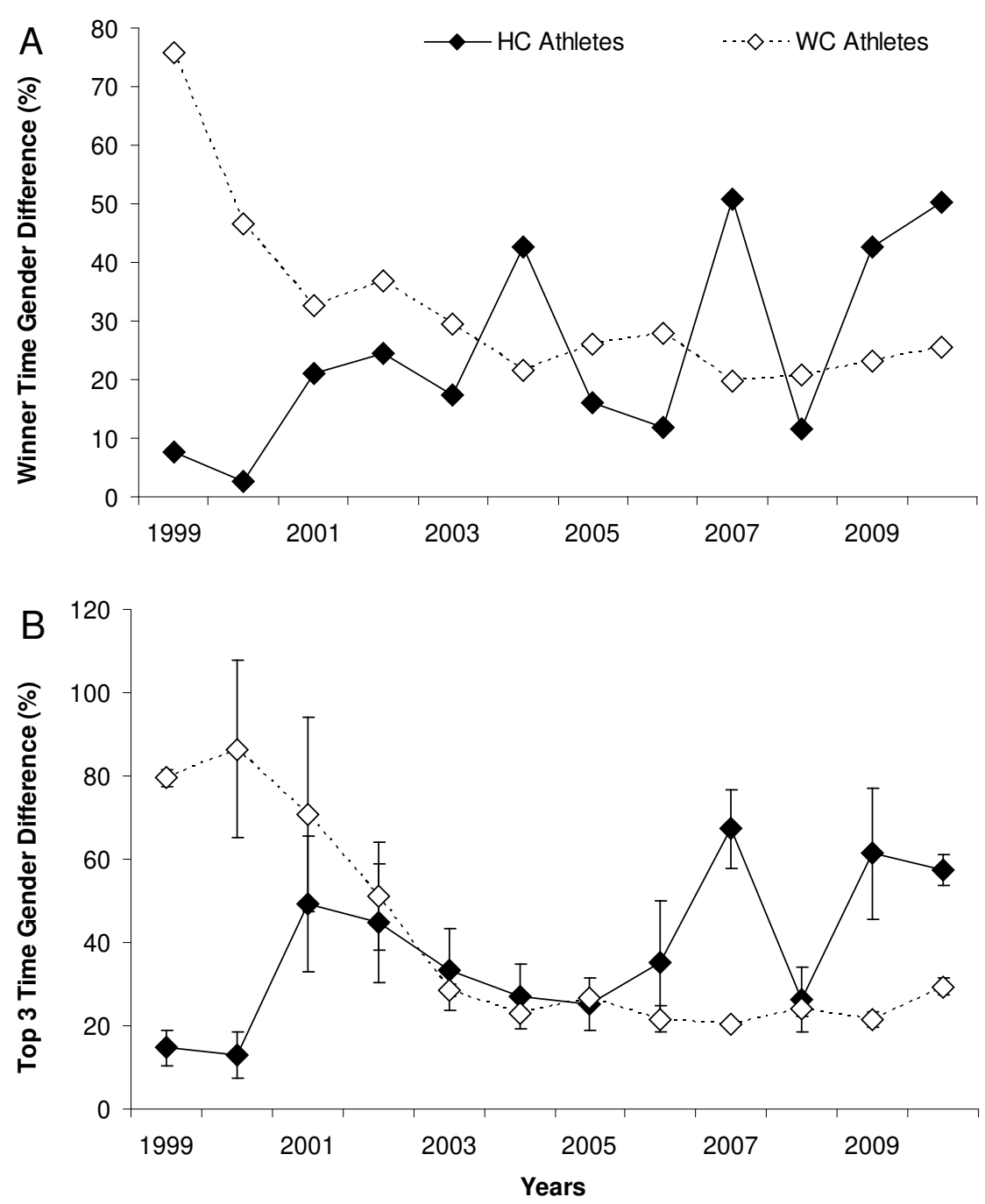